\title{
A Computational Investigation of Icing effects on an S-Duct Inlet
}

\author{
Wonjin Jin', Ray R. Taghavi ${ }^{2}$ and Saeed Farokhi ${ }^{3}$ \\ 'Advanced Aerodynamics \& Structure Department, Korea Aerospace Research Institute, Daejeon, \\ South Korea \\ ${ }^{2 .}{ }^{3}$ Aerospace Engineering Department, The University of Kansas, Lawrence, KS 66045, USA
}

\begin{abstract}
The effects of a typical glaze ice accretion shape on the performance of the M2129 S-duct inlet are computationally investigated for a range of flight Mach numbers. A Reynolds-Averaged Navier-Stokes (RANS) code with $k$ - () turbulence model is used to simulate the compressible viscous flow in the S-duct inlet. The glaze ice accretion on the cowl lip is modeled on a steady-state basis from NASA LEWICE3D code. The results show that the total pressure recovery is reduced and the compressor face distortion level is increased with flight Mach number. A reduction of $22.8 \%$ in total pressure recovery is calculated for a flight Mach number of 0.85 in fully-developed glazed ice condition. The massive flow separations in the inlet induced by the glaze ice horn shapes also create a mass flow reduction in the inlet between 27 and $33 \%$ as compared to clean inlet for flight Mach numbers of 0.13 and 0.475 , respectively. The combined effects of reduced total pressure recovery and the reduced mass flow rate results in a reduction of engine thrust between $\sim 30$ and $60 \%$ from low speed flight to Mach 0.85 .
\end{abstract}

\section{Nomenclature}

\begin{tabular}{ll} 
A & Area $\left(\mathrm{m}^{2}\right)$ \\
a & Semi-major axis of ellipse $(\mathrm{m})$ \\
b & Semi-minor axis of ellipse $(\mathrm{m})$ \\
D & Diameter $(\mathrm{m})$ \\
DP & Total pressure distortion parameter $(\sim)$ \\
$\mathrm{F}_{\mathrm{n}}$ & Thrust $(\mathrm{kN})$ \\
L & Length $(\mathrm{m})$ \\
LWC & Liquid water contents $\left(\mathrm{g} / \mathrm{m}^{3}\right)$ \\
MVD & Mean volume diameter $(\mathrm{mm})$ \\
M & Mach number $(\sim)$ \\
$\mathrm{p}$ & Pressure $(\mathrm{kPa})$ \\
$\mathrm{R}$ & Radius $(\mathrm{m})$ \\
SFC & Specific fuel consumption $(\mathrm{g} / \mathrm{kN} \cdot \mathrm{s})$ \\
T & Temperature $\left({ }^{\circ} \mathrm{C}\right)$ \\
V & Velocity $(\mathrm{m} / \mathrm{s})$ \\
& \\
\hline${ }^{\top}$ Senior Researcher, ${ }^{2}$ Professor
\end{tabular}

$\begin{array}{ll}\mathrm{y}^{+} & \text {Non-dimensional wall distance }(\sim) \\ \mathrm{X}, \mathrm{Y}, \mathrm{Z} & \text { Cartesian coordinates }(\sim) \\ \text { Greek } & \text { Symbols } \\ \alpha & \text { Inlet angle of attack (deg.) } \\ \beta & \text { Inlet sideslip angle (deg.) } \\ \theta & \text { Circumferential angle (deg.) } \\ \rho & \text { Density }\left(\mathrm{g} / \mathrm{m}^{3}\right) \\ \text { Subscripts } \\ \mathrm{cl} & \text { Centerline } \\ \text { ef } & \text { Engine face } \\ \text { max } & \text { Maximum } \\ \text { min } & \text { Minimum } \\ \mathrm{s} & \text { Static } \\ \text { se } & \text { Secondary flow } \\ \mathrm{t} & \text { Total } \\ \text { th } & \text { Inlet throat } \\ \infty & \text { Free-stream }\end{array}$

\section{Superscript}

Area-averaged 


\section{Introduction}

Ice accretes on the surfaces of the aircraft flying through clouds made of super-cooled water droplets. Ice accretions not only on the wings, but also on the engine inlets and tails can seriously impact aircraft operation. A total of 803 aviation accidents and incidents from 1975 to 1988 were caused by inflight icing problems /1/. Therefore, detailed experimental and numerical studies have been carried out to investigate the icing effects on the performance of airfoils and wings $/ 2 /-/ 6 /$. Another aspect of ice accretion is its time dependency. Shin, et. al. /7/ investigated the effect of ice accretion shape as a function of time on airfoil aerodynamic performance. The time constant for ice accretion is usually measured in seconds/minutes and thus our analysis is based on the steady-state calculation of the fully-developed ice shapes on an aircraft inlet. In addition, icing studies have been mainly performed on airfoils and wings with less attention paid to the icing effects on the performance of the aircraft inlets for gas turbine engines, although the effects are equally hazardous to aircraft engines. In particular, the ice accretion on the aircraft inlet lip alters the shape of the inlet lip and cause significant degradation of the performance of an engine inlet.

Acker, et al./8/ first conducted a flight test to investigate icing effects on a turbojet engine and they found ice accretion on the engine inlet resulted in reduction of engine thrust ranging from 9 to 26 percent, and the combined efficiency of the compressor and inlet diffuser were of approximately the same order of magnitude as the thrust losses. Also, Gelder, et al. /9/ studied total pressure distortion and recovery of a full scale unheated supersonic nose inlet in the subsonic icing conditions. Their study showed that in the icing condition of $\mathrm{LWC}=1.3 \mathrm{~g} / \mathrm{m}^{3}$ with $\mathrm{MVD}=16 \mathrm{~mm}$, and in test condition of $M_{\infty}=0.27$, total pressure distortion increased from about 6 percent in clear air to 12.5 percent after 2 minutes. Concurrently, total pressure recovery decreased from about 98 to 94.5 percent. An experimental method was developed by
Papadakis, et al. $/ 10 /$ to determine the water droplet impingement characteristics on 2- and 3-dimensional bodies, including an axisymmetrical aircraft inlet. Bidwell, et al. /11/ calculated the impingement efficiencies and ice shapes for an axisymmetric inlet by using the LEWICE3D/12/ ice accretion program. In their work, a typical rime and glaze ice shape on the axisymmetrical inlet lip were numerically defined in the icing conditions; $V_{\infty}=25 \mathrm{~m} / \mathrm{s}$ : LWC= $0.2 \mathrm{~g} / \mathrm{m}^{3}: \mathrm{Ts}_{\infty}=-29.9^{\circ} \mathrm{C}(243.3 \mathrm{~K})$ and $\mathrm{V}_{\infty}=25 \mathrm{~m} / \mathrm{s}$ : LWC $=0.695 \mathrm{~g} / \mathrm{m}^{3}: \quad \mathrm{Ts}_{\infty}=-9.3^{\circ} \mathrm{C} \quad(263.9 \mathrm{~K})$, respectively $/ 11$.

The M2129 S-duct inlet is characterized by two curvatures with a diffusing shape. The air intake system of aircraft gas-turbine engines, in buried configuration, frequently uses the S-shaped inlet due to its advantages in the installation. However, it is known that a simple $S$-curved duct induces a secondary flow pattern that may cause the flow separation at the first bend, and the secondary flow is further amplified in the second bend of the S-duct. In addition, a diffusing duct has an additional burden of potential flow separation due to the streamwise adverse pressure gradient in the diffuser. Therefore, for the M2129 S-duct inlet, the secondary flow pattern and flow separation contribute to the problem of total pressure loss and inlet distortion. Distortion represents non-uniformity in the flow (see Farokhi $/ 13 /$ ), and the most frequently encountered inlet distortion in flight is total pressure distortion, which is caused by separated boundary layers in the inlet. The level of distortion that an inlet creates at the compressor face affects the stability of the compressor and engine performance. Farokhi /13/ presents the topic of inlet distortion and its impact on compressor stability margin in the context of aircraft jet engines in his recent book.

Moreover, if ice accretes on the lip portion, the efficiency of the S-duct inlet would be substantially affected since the shape of an inlet lip has a direct influence on the quality of the inlet flow. For instance, a sharp inlet lip at the ice-free condition induced higher total pressure loss at the engine face, as compared to a blunt (ellipse) inlet lip, due to lip 
separation /14/. Typically, the ice shapes on the leading edge of wings or inlet lips are categorized into rime and glaze ice, and the examples are shown in Figure 1 /15/.

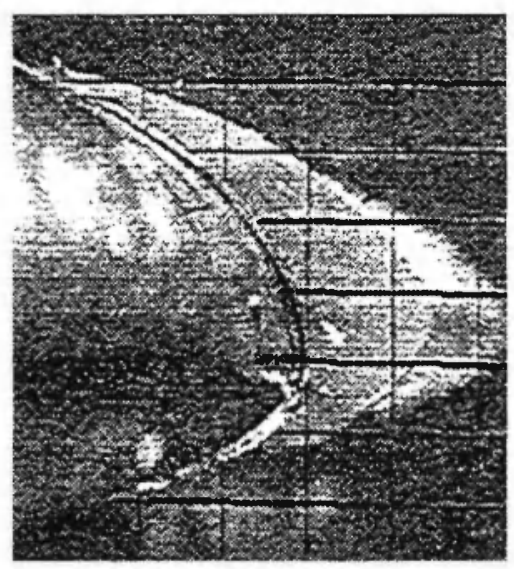

(a) Rime

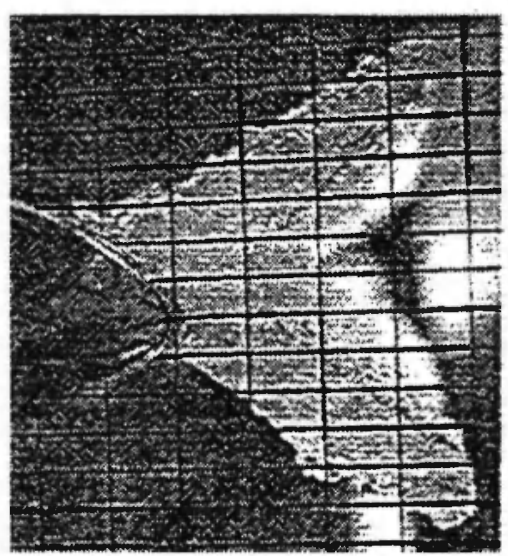

(b) Glaze

Fig. 1: Example of two dominant forms of leading edge icing shapes $/ 15 /$.

The effects of the rime ice accretion, which had a more streamlined shape, on the flow field and performance of the M2129 S-duct inlet were almost negligible $/ 16 \%$. However, a more significant total pressure distortion at the engine face and a more substantial degradation in the inlet performance occurred with the glaze ice shape due to the stronger flow separation from its ice horn. As noted earlier, a diffusing S-duct has an additional disadvantage of flow separation due to streamwise adverse pressure gradient in the diffuser. Therefore, the combined flow separations which were caused by both the inlet icing and inlet-duct geometry contributed to a more serious distortion problem at the engine face at the relatively low-flight Mach number, $\mathrm{M}_{\infty}=0.23 / 16 /$. Furthermore, it is known that the engine face distortion is highly dependent on flight or throat Mach numbers /17/. In particular, supersonic flows, which involve shock formations and shock-boundary layer interactions, can occur in a diffusing S-duct inlet at high-subsonic flight Mach numbers due to the flow acceleration through inlet blockage due to icing and curvatures. Therefore, coupled effects of fully-developed inlet icing and high-subsonic flight Mach numbers on the performance of the M2129 Sduct inlet were computationally investigated in this study. The free-stream Mach number range from $M_{\infty}=0.13$ to 0.85 , was tested, and the corresponding changes in the free-stream temperatures, $\mathrm{Ts}_{\infty}=265.7 \mathrm{~K}$ to $233 \mathrm{~K}$, were considered for the computations. The Reynolds numbers ranged from $\operatorname{Re}=1.74 \times 10^{6}$ to $5.1 \times 10^{6}$, based on the throat diameter of the clean inlet.

Only fully-developed glaze ice shape which produces more severe effects on the duct flow was considered in the present study, and the glaze ice shape was assumed to be symmetrical in the circumferential direction of the inlet lip. In the practical icing conditions, the shape and size of ice accretion are a function of free-stream velocity as demonstrated in numerical studies $/ 11 /$ and experimental icing tests $/ 18 \%$. However, a constant shape and size were assumed (for a single-phase flow) in this investigation to study the changes in inlet flow pattern caused by a fully-developed inlet icing shape at different free-stream Mach numbers.

\section{Numerical methodology}

The M2129 S-duct inlet consists of a diffusing Sbend and two constant-area parts with circular-cross sections, as shown in Figure 2. The geometry of the inlet was taken from $/ 19 /$ and $/ 20 /$. The centerline of the S-bend part is defined by Eq. (1): 
$Z_{\mathrm{cl}}=-\Delta Z_{\mathrm{cl}}\left[1-\cos \left(\pi \mathrm{X}_{\mathrm{cl}} / \mathrm{L}\right)\right]$

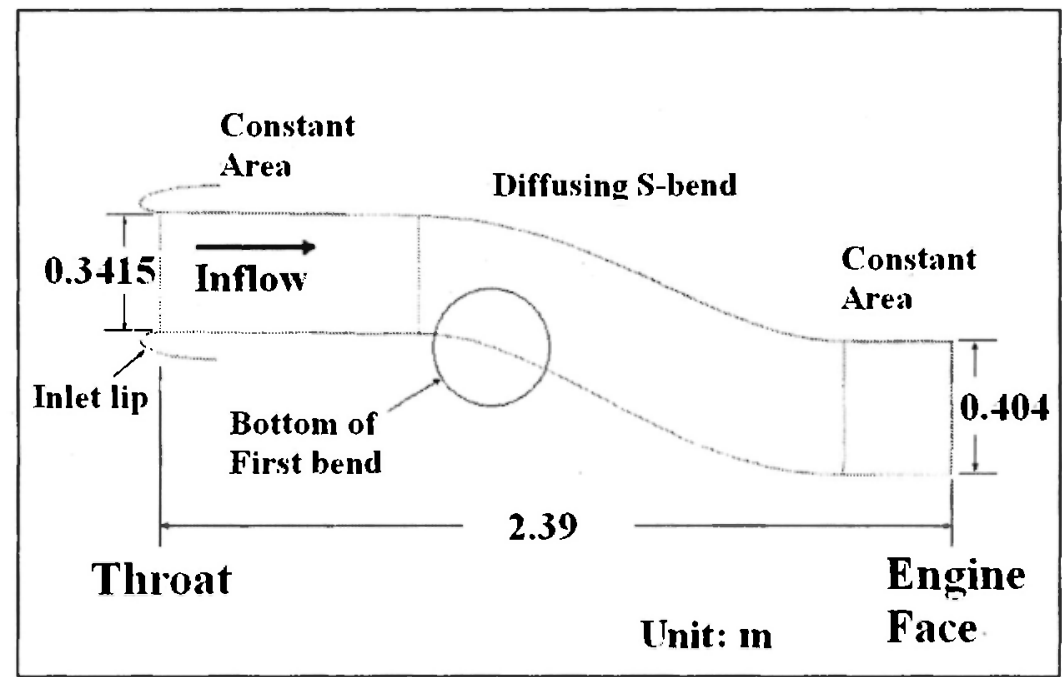

(a) M2129 S-duct inlet

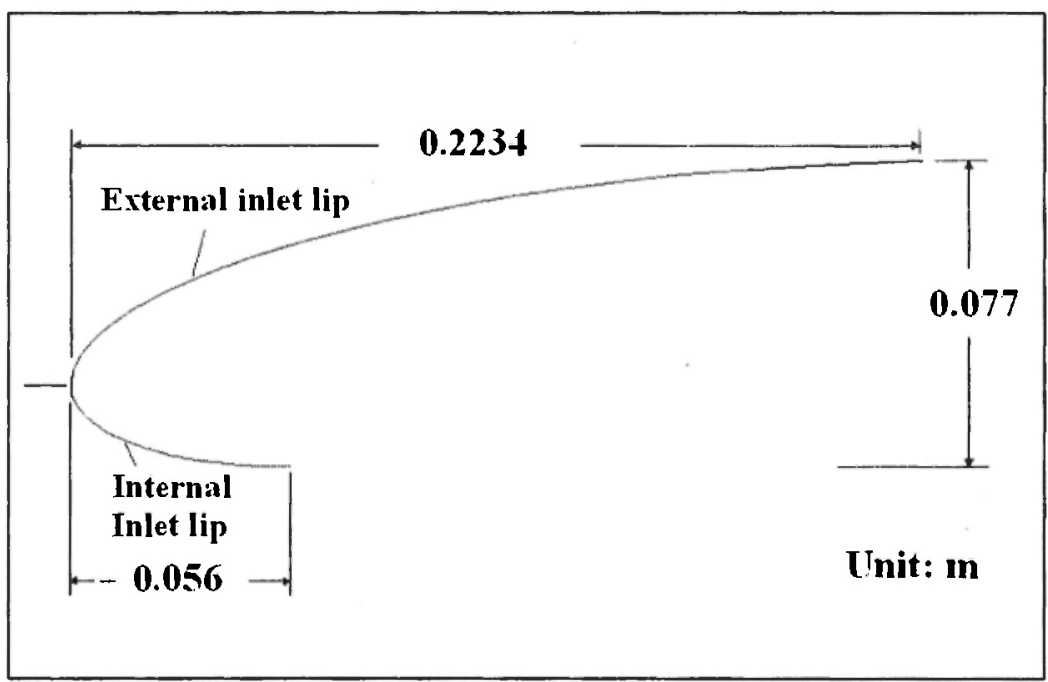

(b) Inlet lip

Fig. 2: Geometry and dimension of M2129 S-duct inlet and inlet lip.

and the radii of circular-cross sections of the S-bend, measured perpendicular to the inlet centerline, are described by Eq. (2):

$\left(\frac{\mathrm{R}-\mathrm{R}_{\mathrm{th}}}{\mathrm{R}_{\mathrm{ef}}-\mathrm{R}_{\mathrm{th}}}\right)=3\left(1-\frac{\mathrm{X}_{\mathrm{cl}}}{\mathrm{L}}\right)^{4}-4\left(1-\frac{\mathrm{X}_{\mathrm{cl}}}{\mathrm{L}}\right)^{3}+1$ 
Note that the entrance and outlet of the inlet are defined by throat and engine face, respectively, as shown in Figure 2. The constant-area parts extend from the S-bend to the throat and engine face by 2 $D_{t h}$ and $1 D_{t h}$, respectively. In addition, the area ratio of the engine face to throat is approximately 1.4 , and the total inlet length is about $7 \mathrm{D}_{\text {th }}$. In the current study, however, the inlet size was set according to the diameter of an axisymmetric inlet in $110 \%$. The geometry and size of the inlet lip were also defined based on $/ 10 \%$. The shape of the inlet lip is elliptical and the ellipse ratio of the external and internal lip is $\mathrm{a} / \mathrm{b}=4.0$ and 2.5 , respectively.

The glaze ice shape investigated in this study was based on the Bidwell's /1 / 2-dimensional ice shape on an axisymmetric inlet lip which was numerically predicted by LEWICE3D code as shown in Figure 3.

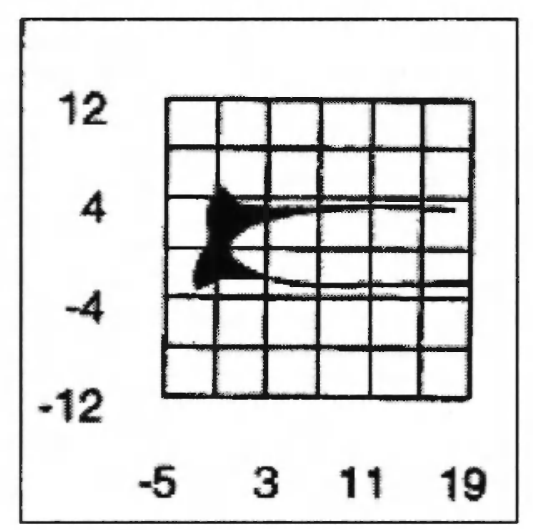

Fig. 3: Numerically-predicted glaze ice shape /11/ by LEWICE3D

The icing condition was based on zero inlet flow angularity, i.e., $\alpha=\beta=0^{\circ}, \mathrm{M}_{\infty}=0.23, \mathrm{~V}_{\infty}=75 \mathrm{~m} / \mathrm{s}$, $\mathrm{Ts}_{\infty}=263.9 \mathrm{~K}, \mathrm{LWC}=0.695 \mathrm{~g} / \mathrm{m}^{3}, \mathrm{MVD}=20.36 \mathrm{~mm}$, and icing time $=30 \mathrm{~min} . / 11 /$. For the present study, the Bidwell's ice shape was reconstructed on the inlet lip of the M2129 S-duct inlet using the GAMBIT 2.2.30 software $/ 21 /$ as shown in Figure 4. Here, a relatively rough surface of real glaze ice was assumed to be smooth, therefore, an additional roughness effect was not considered; the

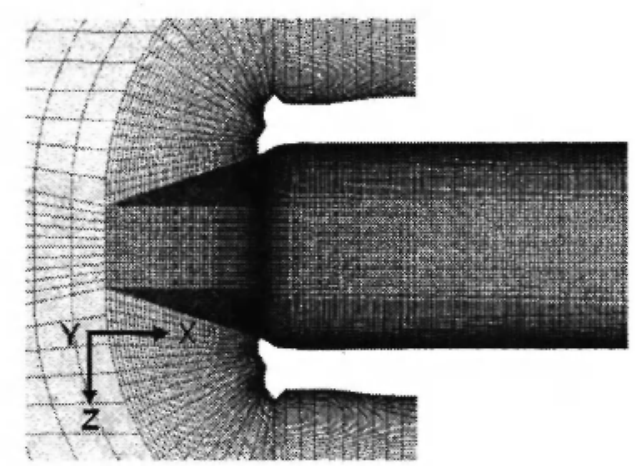

Fig. 4: Mesh generation for the glaze-iced inlet lip

observations focused on the effect of fullydeveloped ice geometry, in particular glaze ice horn. In addition, as shown in Figure 4, the rear part in the upper-glaze ice horn, which forms on the outside of the inlet lip and exerts no influence on the duct internal flow, was further simplified. Figure 5 shows the 3-dimensional modeling and mesh generation for the clean and glaze-iced inlet lip.

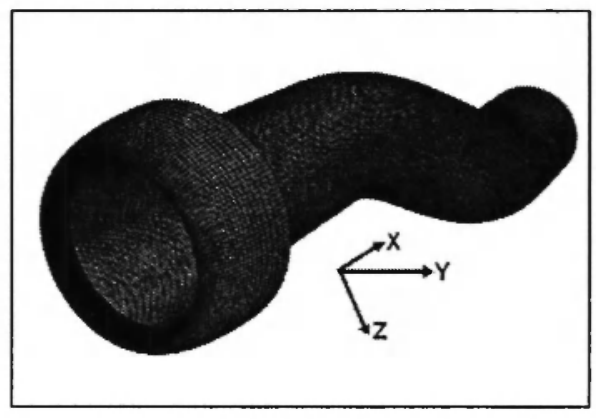

(a) Clean inlet lip

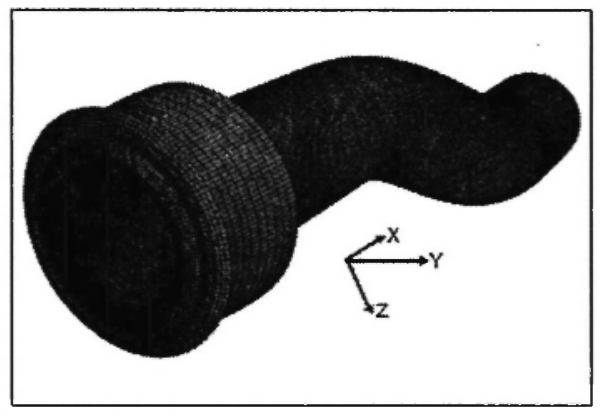

Glaze-iced inlet lip

(b)

Fig. 5: Three-dimensional modeling and mesh generation 
Note that the 3-dimensional modeling of the glaze ice was achieved by extending the two-dimensional ice shape in the circumferential direction of the inlet lip as indicated in Figure 5(b); therefore, the glaze ice shape is assumed to be circumferentially symmetrical. Also, note that the inlet frontal area is decreased by 21 percent by the simulated glaze ice. The circumferential or azimuthal angle $(\theta)$ for the M2129 S-duct inlet is defined in Figure 6. Using this definition, the stations with the concave and convex corner of the first bend are denoted by top $\left(\theta=0^{\circ}\right)$ and bottom $\left(\theta=180^{\circ}\right)$, respectively.

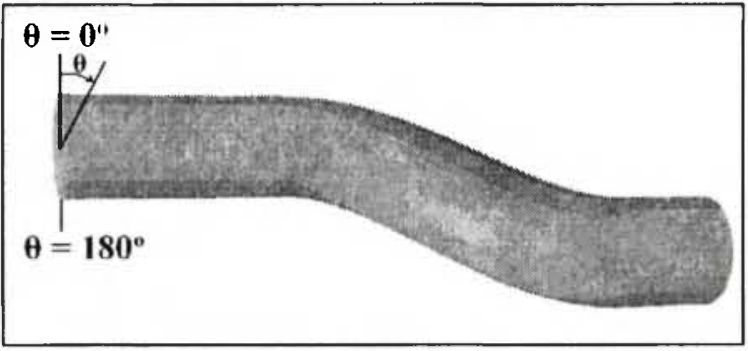

Fig. 6: Definition of circumferential angle $(\theta)$

All computational simulations in this study were carried out using a commercial CFD code, STAR$\mathrm{CCM}+2.10 .013 / 22 \%$. The far-field (free-stream) boundary condition was used for all the outer boundaries to simulate the free-stream condition at infinity. In particular, the far-field boundaries that encompass the inlet lip region were radially extended by $\sim 20 D_{\text {th }}$ into $x-, y-$, and $z$-direction upstream to prevent boundary effects on the simulation regions of interest, as shown in Figure 7.

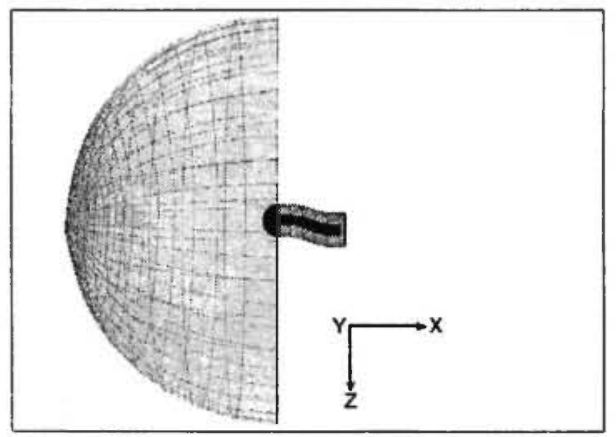

Fig. 7: Extension of a far-filed boundary
Also, the inner and outer surfaces of the duct, and the cowl surface, including the iced lip region, were defined by the adiabatic wall boundary condition, and no convective/conductive/radiative wall heat transfer was thus considered. In addition, the cross-sectional stations inside the duct, including the engine face station, were defined to see the icing effects on the internal flow field and inlet performance. Figure 8 shows the mesh generations for the outer and inner boundaries around the S-duct inlet. Using the GAMBIT software, the structured meshes for the iced inlet lip, S-duct with inner regions, and far-field boundary were generated for a total of 66 volumes.

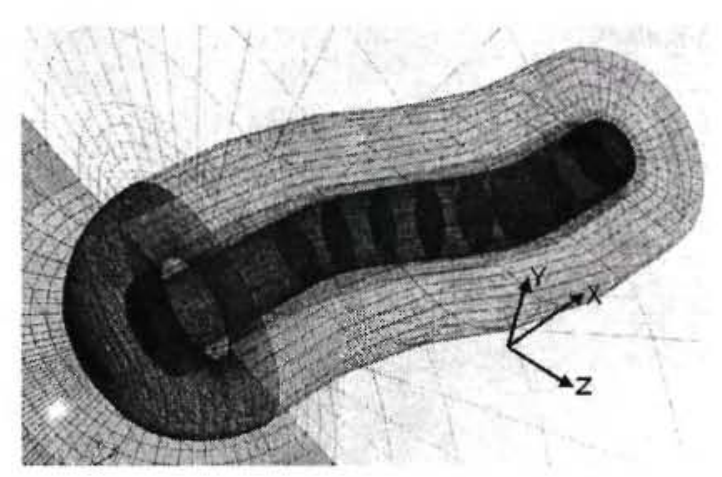

Fig. 8: Mesh generations for outer and inner boundaries of M2129 S-duct inlet (clean inlet)

Also, the mesh density after the glaze ice was increased to properly capture the expected flow separation from the glaze ice horn, as shown in Figure 4. The number of mesh nodes in the duct section was $230 \times 160 \times 100$ in the streamwise, circumferential, and radial direction respectively for the clean and ice cases. The total numbers of mesh cells for all parts including the inlet lip and the farfield region were approximately 3.7 and 5.2 million for the clean and glaze iced inlets, respectively. Note that those cell numbers were fixed over the range of the free-stream Mach number. Also, the mesh resolution in the near-wall region of turbulent boundary layers, represented by $\mathrm{y}^{+}$, is a critical issue in the computational simulations of turbulent flows that employ wall function in turbulence modeling. 
In particular, a study on the mesh resolution showed that the accurate prediction of the flow separation and distortion in the M2129 S-duct inlet depended on the proper choice of $\mathrm{y}^{+} / 23 /$. Therefore, the all $y$ wall treatment option in STAR-CCM+ was chosen to have reasonable results in the turbulent boundary layers at different free-stream Mach numbers. By applying the wall treatment, the limitation of meshes with low and high $\mathrm{y}^{+}$can be improved, and a more accurate turbulence modeling can be formulated in the near wall region of the iced inlet lip and duct.

Using a variety of turbulence models, a validation study with experimental data /24/ was also carried out. Although many turbulence models produced reasonable results, the Shear Stress Transport (SST) $k$ - $\omega$ model $/ 25 /$ showed the best performance for the baseline S-duct inlet. The use of the SST $k$ - $\omega$ turbulence modeling in S-shape diffusers with vortex separation and compressible flow in transonic diffusers is also supported by other researchers $126-28 \%$. The coupled-implicit solver for the steady-state condition was utilized for the flow simulations, and the second-order upwind scheme was applied for the spatial discretization. Also, the density change option using the ideal gas law was chosen during the computations since compressibleviscous flow effects were expected due to the flow acceleration inside the S-duct at the higher freestream Mach numbers.

The ambient pressure at sea level was imposed on the far-field boundary condition as the free-steam total pressure, $\mathrm{p}_{\mathrm{t} \infty}=101,125.4 \mathrm{~Pa}$. According to the studied Mach numbers; $M_{\infty}=0.13$ to 0.85 , the freestream static pressure range: $p_{\infty}=99,942.2 \mathrm{~Pa}$ to $63,051.7 \mathrm{~Pa}$ and temperature range: $\mathrm{Ts}_{\infty}=265.7 \mathrm{~K}$ to $233 \mathrm{~K}$, based on the glaze-icing temperature $\left(\mathrm{Ts}_{\infty}=263.9 \mathrm{~K}\right.$ at $\mathrm{M}_{\infty}=0.23$ ) by Bidwell, et al. $/ \mathrm{I} \mathrm{I} /$ were applied to the far-field boundary condition. Other physical properties of air, such as viscosity and air-thermal conductivity, were also defined according to the icing condition in $/ 11 \%$.

All simulations were performed on the computing cluster at the Information and Telecommunication Technology Center (ITTC) at the University of Kansas. For the parallel computations, each simulation case was distributed among eight to twenty processors according to the mesh sizes. Each node has two Intel ${ }^{(8)} \mathrm{Xeon}^{\text {[R }}$ EM64T processors at $3.2 \mathrm{GHz}$ and $4,096 \mathrm{MB}$ of RAM. The simulations were run and monitored until the residuals for continuity equation, $x, y, z-$ velocity, energy equation, and turbulence factors dropped below $10^{-4}$ to $10^{-5}$ where the value of the area-averaged total pressure at the engine face changed by less than 0.5 percent between runs.

\section{Validation of Numerical Solutions}

The validation of the numerical solutions by STAR-CCM+ was conducted for the baseline M2129 S-duct inlet. From the investigation by AGARD Working Group $13 / 24 /$, the experimental measurement data for the performance of an M2129 inlet, generally represented by total pressure recovery, were available for the baseline configuration only; however, no validation data has been found for the icing cases. Also, the computational data for the baseline M2129 inlet using WIND-US code from $/ 29 /$ were provided for the comparison. For this validation, the size of the duct inlet was set based on the geometrical data from /24/ and /29/. According to the modeling approach for the baseline M2129 inlet in $/ 29 /$, only half of the geometry was meshed due to the symmetry across the mid plane with the reflecting boundary condition, and the inlet lip and far-field region were not considered. Consequently, the pressure-inlet and pressure-outlet boundary condition was applied to the computational domain, and the static pressure at the engine face was varied to obtain the throat Mach number range, $\mathrm{M}_{\mathrm{th}}=0.1$ to 0.77 . The main features of computational setup, including the mesh size and turbulence model, for STAR-CCM+ and WIND-US are listed in Table 1.

As shown in Figure 9, the total pressure recovery result by STAR-CCM+ is compared to the experimental data and WIND-US result. The total 
Table 1

Computational setups for STAR-CCM+ and WIND-US /27/

\begin{tabular}{|c|c|c|c|c|c|c|c|}
\hline Code & Ice & Inlet lip & Mesh type & $\begin{array}{l}\text { Meshe } \\
\text { d Part }\end{array}$ & $\begin{array}{c}\text { Mesh size } \\
\text { (Total cell } \\
\text { No.) } \\
\end{array}$ & $\begin{array}{l}\text { Boundary } \\
\text { condition }\end{array}$ & $\begin{array}{c}\text { Turbulent } \\
\text { model }\end{array}$ \\
\hline $\begin{array}{l}\text { STAR- } \\
\text { CCM+ }\end{array}$ & \multirow[b]{2}{*}{ No } & \multirow{2}{*}{$\begin{array}{c}\text { No } \\
\text { (baseline } \\
\text {-inet) }\end{array}$} & Structured & \multirow{2}{*}{$\begin{array}{l}\text { Half } \\
\text { Plane }\end{array}$} & 180,000 & \multirow{2}{*}{$\begin{array}{l}\text { Pressure } \\
\text { inlet- } \\
\text { Pressure } \\
\text { outlet }\end{array}$} & SST $k-\omega$ \\
\hline $\begin{array}{l}\text { WIND } \\
\text {-US } \\
127 /\end{array}$ & & & $\begin{array}{c}\text { Unstructure } \\
\text { d }\end{array}$ & & 830,000 & & $\begin{array}{l}\text { Spalart- } \\
\text { Allmaras }\end{array}$ \\
\hline
\end{tabular}

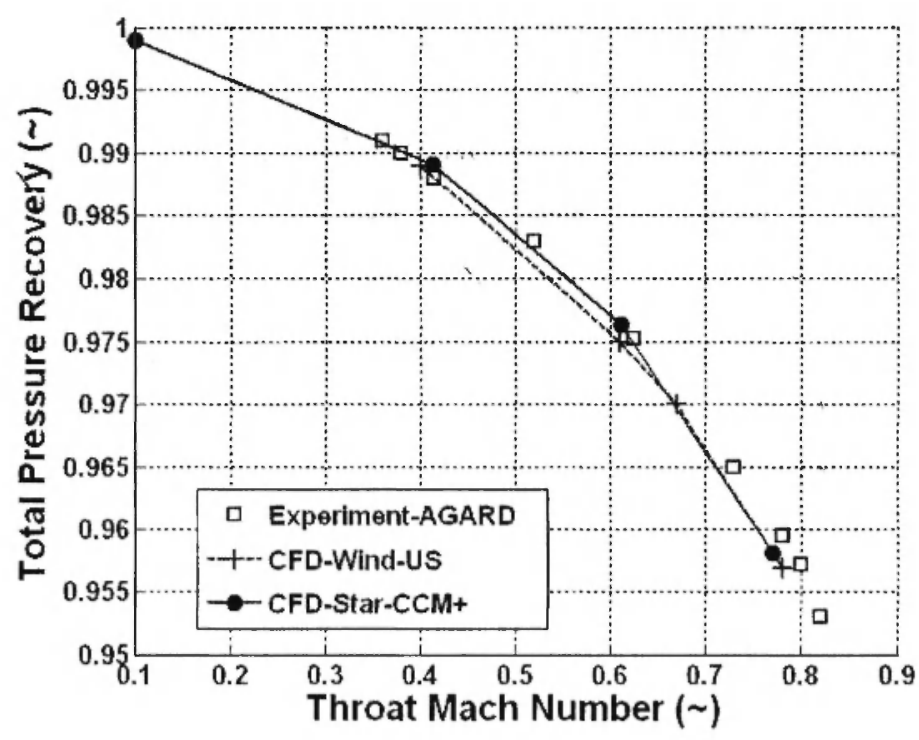

Fig. 9: Total pressure recovery $\left(\overline{\mathrm{p}}_{\mathrm{tef}} / \mathrm{p}_{\mathrm{t} \mathrm{c}}\right)$ in the baseline M2129 S-duct inlet

pressure recovery, the area-averaged total pressure at the engine face normalized to the free-stream total pressure $\left(\overline{\mathrm{p}}_{\mathrm{t} \text {.ef }} / \mathrm{p}_{\mathrm{t}+o}\right)$, measures the extent of reversibly-decelerated free-stream flow into an engine compressor, and is the important factor for evaluating the inlet operational efficiency. Furthermore, the total pressure loss in an S-shaped inlet is primarily caused by the flow separation at the first bend and subsequent turbulent mixing downstream. Also, Figure 9 indicates that total pressure recovery decreases as the throat Mach number increases, as expected. The enhanced flow separation and turbulent mixing with the higherspeed duct flow are represented by the lower-total pressure recovery and higher-engine face distortion. In Figure 9 it can be seen that STAR-CCM+ accurately predicts the experimental measurements, showing a similar variation and level of total pressure recovery with increasing throat Mach number. In particular, a relatively good agreement is obtained by STAR-CCM+ near $\mathrm{M}_{\mathrm{th}}=0.8$, where the strong flow separation and mixing are expected: the STAR-CCM+ total pressure recovery result is 0.958 for $\mathrm{M}_{\mathrm{th}}=0.77$, while the experimental result is about 0.96 for $\mathrm{M}_{\mathrm{th}}=0.78 / 24 /$. Also, compared to the WIND-US data, STAR-CCM+ produces a wellmatched characteristic of total pressure recovery, although the mesh generation and turbulence 
modeling for both codes are different. As noted in Table 1, the structured mesh with the SST $k$ - $\omega$ model and the unstructured mesh with the oneequation turbulence model of Spalart-Almaras were utilized in STAR-CCM+ and WIND-US code, respectively. In addition, the difference in mesh sizes for both codes ( 0.18 vs. 0.83 million) is expected to induce a minor discrepancy in the simulations of the inlet performance. The total pressure recovery by WIND-US is 0.957 at $\mathrm{M}_{\mathrm{th}}=0.78$ $129 \%$

The performance of STAR-CCM+ and the effect of mesh size for the iced inlet cases were also evaluated. Again, the experimental data for iced Sduct inlets are not available; therefore, the validity of STAR-CCM+ for the glaze-iced M2129 inlet was assessed through two mesh densities and a comparison with another CFD code, FLUENT /30/. Both the clean and glaze-iced inlets were tested, and the inlet lip and far-field region were included to the meshes in order to simulate the ice on the inlet lip. The inlet size and the inlet-lip shape were taken from $/ 10 \%$. Based on the glaze cases, the total cell number of the coarse mesh was about 15 percent of that of the fine mesh, since the mesh covered only half the geometry according to the symmetry plane with fewer nodal numbers as shown in Table 2. STAR-CCM+ solved the fine mesh cases, while FLUENT was dedicated for the coarse-mesh cases, using the same turbulence modeling, the SST $k-\omega$. Other computational parameters, such as boundary conditions and solver choice, were set up as listed in the previous section.

Table 2

Mesh generation for STAR-CCM+ and FLUENT $\left({ }^{*}\right.$ Streamwise $\times$ circumferential $\times$ radial direction).

\begin{tabular}{|c|c|c|c|c|c|c|c|}
\hline \multicolumn{2}{|c|}{ Case } & Code & Inlet lip & $\begin{array}{l}\text { Mesh } \\
\text { type }\end{array}$ & $\begin{array}{l}\text { Meshed } \\
\text { part }\end{array}$ & $\begin{array}{l}\text { Mesh nodal No. } \\
\text { (Duct only) }\end{array}$ & $\begin{array}{l}\text { Total cell } \\
\text { No. } \\
\text { (Including } \\
\text { Far-field } \\
\text { region) }\end{array}$ \\
\hline \multirow{2}{*}{$\begin{array}{c}\text { Coars } \\
\mathrm{e}\end{array}$} & Clea & \multirow{2}{*}{ FLUENT } & \multirow{4}{*}{$\begin{array}{l}\text { Yes } \\
\text { (Including } \\
\text { Far-field } \\
\text { region) }\end{array}$} & \multirow{4}{*}{$\begin{array}{c}\text { Structure } \\
\mathrm{d}\end{array}$} & \multirow{2}{*}{ Half plane } & \multirow{2}{*}{$140 \times 40$ (half $) \times 70^{*}$} & 651,200 \\
\hline & Glaz & & & & & & 771,200 \\
\hline \multirow{2}{*}{ Fine } & $\begin{array}{c}\text { Clea } \\
\mathrm{n}\end{array}$ & \multirow{2}{*}{$\begin{array}{l}\text { STAR- } \\
\text { CCM+ }\end{array}$} & & & \multirow{2}{*}{ Whole } & \multirow{2}{*}{$\begin{array}{c}230 \times 160(\text { whole }) \times \\
100^{*}\end{array}$} & $3,722,300$ \\
\hline & $\begin{array}{c}\text { Glaz } \\
\text { e }\end{array}$ & & & & & & $5,194,300$ \\
\hline
\end{tabular}

Table 3

Total pressure recovery by two mesh density levels

\begin{tabular}{ccccc}
\hline \multirow{2}{*}{$\mathrm{M}_{\infty}$} & \multicolumn{2}{c}{ Clean } & \multicolumn{2}{c}{ Glaze } \\
& Coarse & Fine & Coarse & Fine \\
\hline 0.13 & 0.996 & 0.998 & 0.985 & 0.985 \\
0.25 & 0.989 & 0.992 & 0.949 & 0.949 \\
0.34 & 0.977 & 0.978 & 0.907 & 0.910 \\
0.475 & 0.940 & 0.947 & 0.836 & 0.836 \\
0.65 & 0.845 & 0.843 & 0.725 & 0.719 \\
0.85 & 0.791 & 0.789 & 0.619 & 0.610 \\
\hline
\end{tabular}


Table 3 shows the effect of mesh density in terms of total pressure recovery for the free-stream Mach number range, $\mathrm{M}_{\infty}=0.13$ to 0.85 . We first note that the total pressure recoveries generated from the two mesh density levels are in relatively good agreement for both the clean and glaze cases up to $\mathrm{M}_{\infty}=0.85$, and the deviation caused by different computational dissipations between STAR-CCM+ and FLUENT seems to be insignificant. The glazeiced inlet was assumed to be more susceptible to the mesh density due to the anticipated flow separation from the ice formation on the inlet lip. For the glaze cases, however, the coarse mesh (with FLUENT) yields the deviation of only about 1.5 percent in total pressure recovery at $\mathrm{M}_{\infty}=0.85$, and this deviation is the maximum throughout all cases and Mach numbers, as indicated in Table 3. Therefore, it can be concluded that STAR-CCM+ is still properly computing the performance of the M2129-S duct inlet under the icing effects, showing a relatively high-mesh independency. Despite the increase in computational efforts, the fine meshes with the whole geometrical modeling were employed for the following computations, as noted in the previous section: about 3.7 and 5.2 million cells for the clean and gaze case, respectively.

\section{Results and Discussion}

Figure 10 shows the Mach number distribution in the duct symmetry plane for both the clean and glaze ice cases, as the free-stream Mach number increases from $\mathrm{M}_{\infty}=0.25$ to 0.85 . In Figure 10(a) and (b), the clean cases show the flow deceleration and acceleration at the top $\left(0=0^{\circ}\right.$, i.e., concave) and bottom ( $\theta=180^{\circ}$, i.e., convex) surfaces, respectively, of the first bend of the S-duct inlet. This typical flow pattern in a clean S-shaped inlet is the result of the curved flow centrifugal pressure gradient at the first bend that induces the inlet flow separation at the bottom side by swirl or the secondary flow /31/. The inlet flow separates more severely from the first bend at the higher free-stream Mach number as presented in the clean case of Figure 10(b). This is reasonable since the centrifugal pressure gradient is proportional to the mainstream velocity of the inlet flow $/ 31 \%$ On the other hand, the flow and boundary layers separate at the glaze ice horn and the flow separation at the first bend becomes more massive as seen in the glaze ice case of Figure 10(a) and (b). A relatively strong pressure gradient over the glaze ice horn causes the duct internal flow to separate, and the flow with lower energy aggravates the flow separation at the first bend of the S-duct inlet. Furthermore, in both clean and glaze ice cases a supercritical flow, where the local Mach number is 1 , occurs in the free-stream Mach number range between $\mathrm{M}_{\infty}=0.25$ and 0.475 . The difference in the local supersonic regions of the clean and glaze ice cases is their location as seen in Figure 10(b). For the clean inlet case, the flow accelerates to a supersonic velocity at the bottom of the first bend which is indicated in Figure 10(b). On the other hand, the glaze ice case shows the supersonic region forming at the inlet throat due to the much diminished-effective throat area by the flow separation from the glaze ice. As the free-stream Mach number increases up to $M_{\infty}=0.65$, the interacting oblique shocks of opposite family and their multiple reflections from the wall are visible in the glaze ice case as shown in Figure 10(c). At $\mathrm{M}_{\infty}=0.85$, the multiple shock cells persist into the first and second bends of the S-duct as presented in Figure 10(d). Moreover, compared to the $\mathrm{M}_{\infty}=0.65$ case, the flow separation at the first bend of the glaze case is more intense with a stronger pressure gradient, which is indicated by the comparably lower and higher Mach number region at the top and bottom sides, respectively, of the first bend. In addition, the expected total pressure decrease after the multiple shock cell structure, caused by the glaze ice accretion, is clearly another source of total pressure loss at the engine face. Note that in the clean case at $\mathrm{M}_{\infty}=0.85$, there is no flow separation at the first bend. Instead, the supersonic flow accelerates until the second bend due to its diffusing duct shape, and a flow separation occurs at the top side of the second bend. 


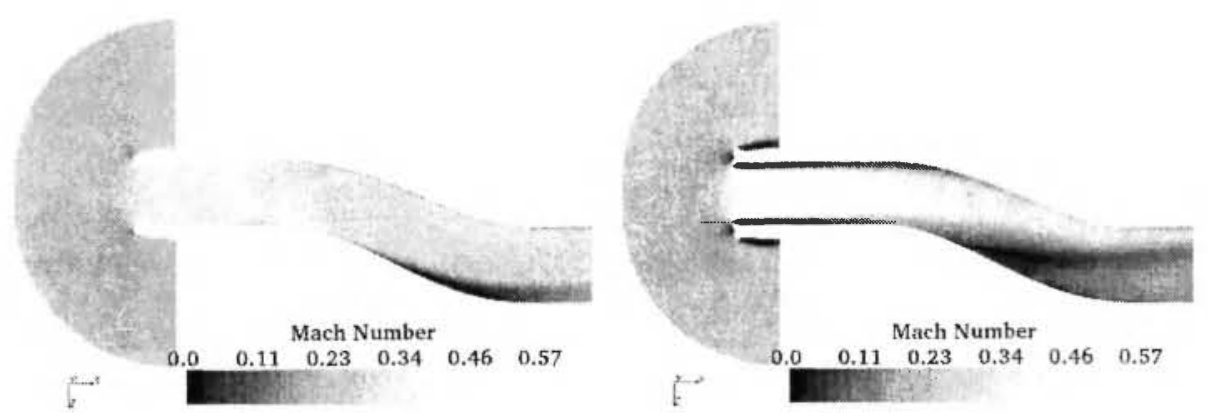

(a) $\mathrm{M}_{s}=0.25$ (range: $\mathrm{M}=0.0-0.57$ )

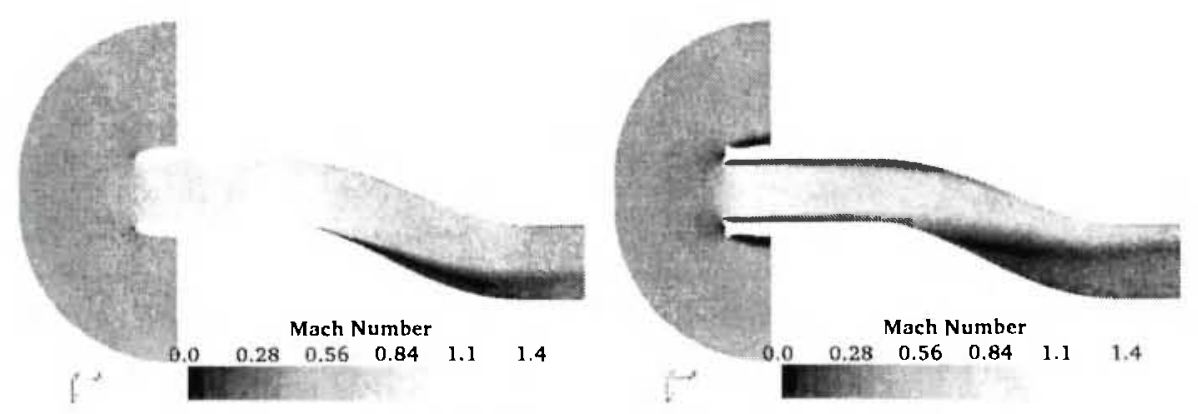

(b) $M_{\infty}=0.475$ (range: $M=0.0-1.4$ )
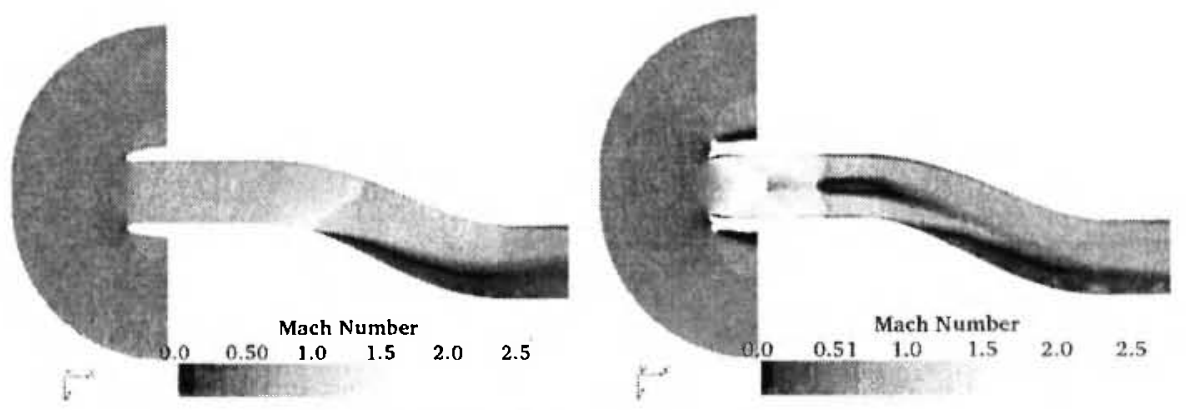

(c) $M_{s}=0.65$ (range: $\left.M=0.0-2.5\right)$
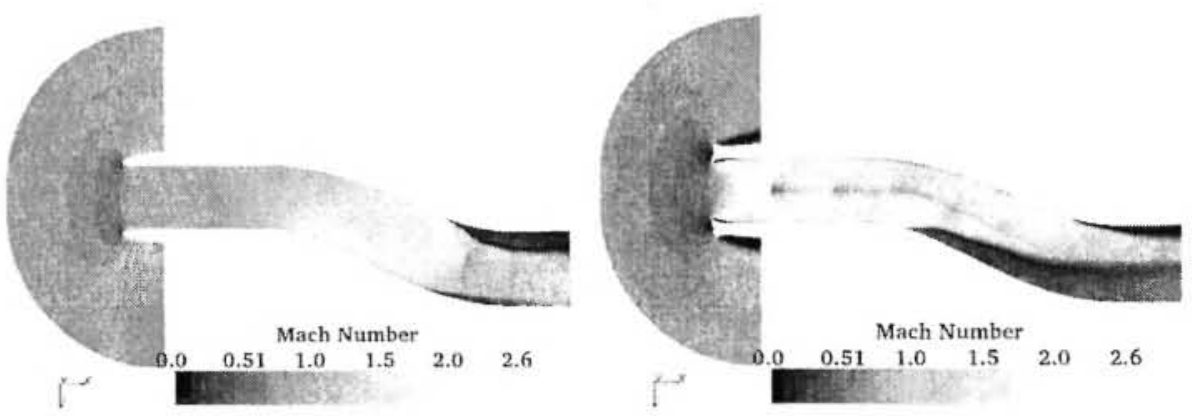

(d) $\mathrm{M}_{\infty}=0.85$ (range: $\mathrm{M}=0.0-2.6$ )

\section{i. Clean}

Fig. 10: Mach number distributions in the duct symmetry plane with free-stream Mach numbers 

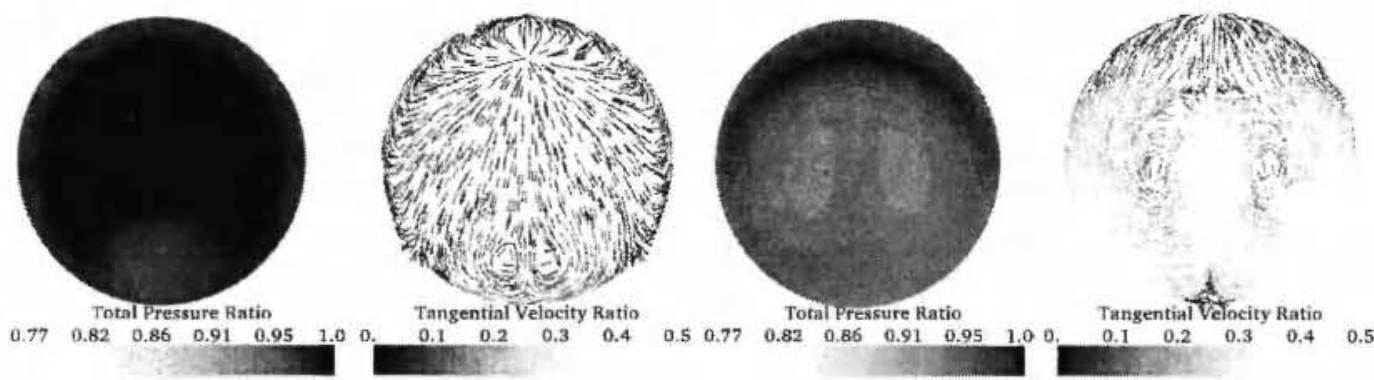

(a) $\mathrm{M}_{\infty}=0.25\left(\mathrm{p}_{\mathrm{V}} / \mathrm{p}_{\mathrm{t} \infty}=0.77-1.0, \mathrm{p}_{\mathrm{t \omega}}=101.1 \mathrm{kPa}\right.$, and $\left.\mathrm{V}_{\mathrm{se}} / \mathrm{V}_{\infty}=0.0-0.5\right)$
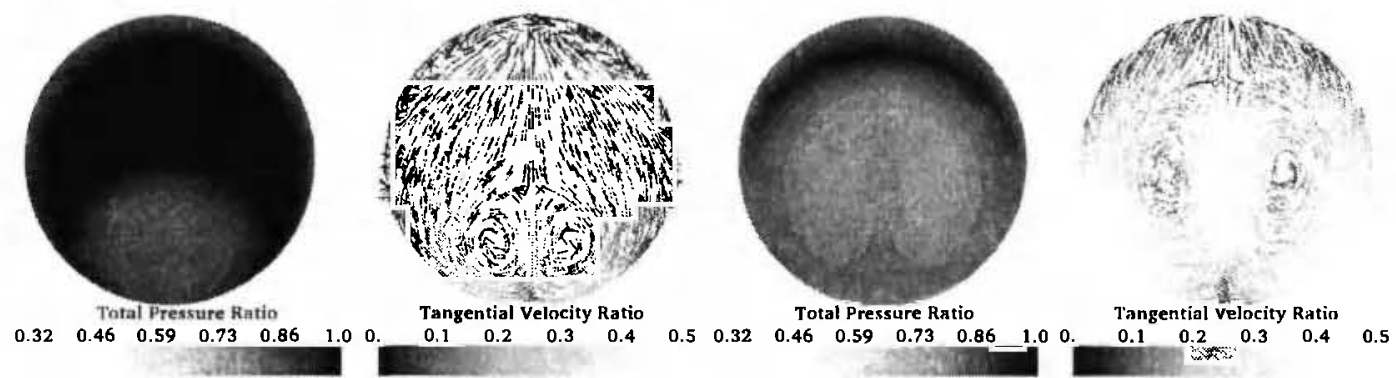

(b) $\mathrm{M}_{\infty}=0.475\left(\mathrm{p}_{\mathrm{t}} / \mathrm{p}_{+\infty}=0.32-1.0, \mathrm{p}_{\mathrm{t} \infty}=101.1 \mathrm{kPa}\right.$, and $\left.\mathrm{V}_{\mathrm{se}} / \mathrm{V}_{\infty}=0.0-0.5\right)$
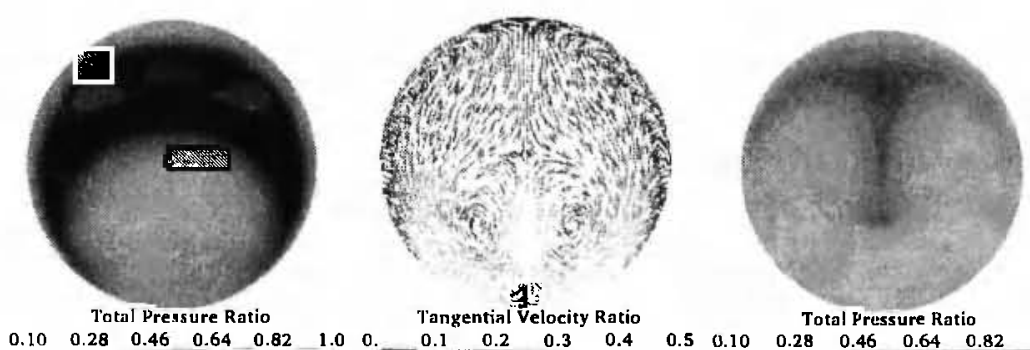

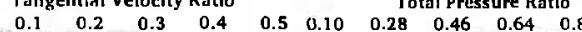

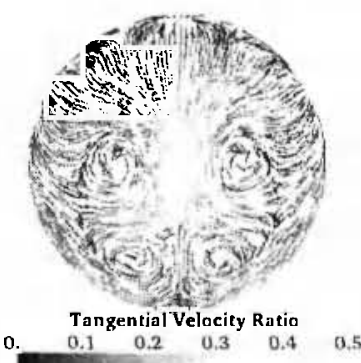

(c) $\mathrm{M}_{\infty}=0.65\left(\mathrm{p}_{\mathrm{l}} / \mathrm{p}_{1 \infty}=0.1-1.0, \mathrm{p}_{\mathrm{t \infty}}=101.1 \mathrm{kPa}\right.$, and $\left.\mathrm{V}_{\mathrm{se}} / \mathrm{V}_{\infty}=0.0-0.5\right)$
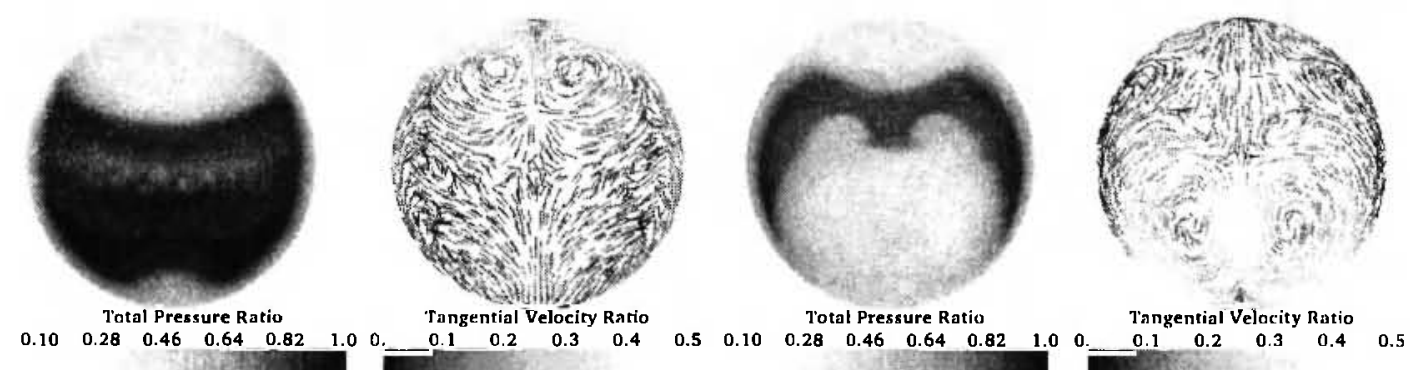

(d) $\mathrm{M}_{\infty}=0.85\left(\mathrm{p}_{\mathrm{l}} / \mathrm{p}_{+\infty}=0.1-1.0, \mathrm{p}_{\mathrm{t} \infty}=101.1 \mathrm{kPa}\right.$, and $\left.\mathrm{V}_{\mathrm{se}} / \mathrm{V}_{\infty}=0.0-0.5\right)$
i. Clean
ii. Glaze

Fig. 11: Total pressure contours and the secondary flow fields at the engine face with free-stream Mach numbers. 
The total pressure ratio $\left(\mathrm{p}_{\mathrm{t}} / \mathrm{p}_{\mathrm{t} \infty}\right)$ patterns and the secondary flow fields at the engine face are compared in Figure 11. The secondary flow vectors are given in the form of the vector of the secondaryflow velocity magnitude $\left(\mathbf{V}_{\mathbf{s e}}\right)$ divided by the freestream velocity $\left(V_{\infty}\right)$ at each $M_{\infty}$. It is known that the secondary flow in the flow separation at the first bend of the clean S-duct inlet is further amplified, azimuthally rotates through the second bend, and affects the overall flow quality at the engine face in terms of inlet distortion, even though the impact on the engine performance could be insignificant. The typical secondary flow pattern at the engine face of the clean inlet shown in Figure 11(a) is characterized by a pair of counter-rotating vortices. The region of intense secondary flow with swirl that has caused flow separation is also represented by the total pressure loss region on the lower part of the duct, as shown in the same figure. Furthermore we note that the size and intensity of the counterrotating vortex pattern, as well as the region of total pressure loss, increases with increasing free-stream Mach number for the clean cases, as shown in Figure 11(a) to (c). However we notice a significant change in secondary flow pattern at $M_{\infty c}=0.85$, exhibiting the migration of the counterrotating vortex pair towards the top of the duct. The reason behind this migration is seen in Figure 10. At Mach 0.65, an oblique shock is formed at the first bend, with a shock-induced separation that is on the lower part of the duct (see Figure 10 (c)). For Mach 0.85 , the shock structure is pushed further att and is in the second bend with shock-induced flow separation on the upper part of the duct. For the glaze ice cases, the size and intensity of the swirling flow pattern becomes larger due to stronger shock formations. A nearly-periodic shock cell structure is formed at freestream Mach numbers of 0.65 and 0.85 (see Figure 10 (c) and (d)) that are created at the throat and are stretched along the duct axis and cause flow separation on the lower wall. As a result, a complex secondary flow pattern is created that involves the formation of two pairs of counterrotating vortices at the engine face with a potential of causing compressor stall. In general we observe that inlet icing impacts the core flow as well as the near wall region of the inlet duct. The core experiences oblique shock formation (of opposite family), interaction and reflection of those shocks with the wall boundary layer creates massive regions of separated flows and thus engine face distortion. These effects are magnified with increasing free stream Mach number, as expected.

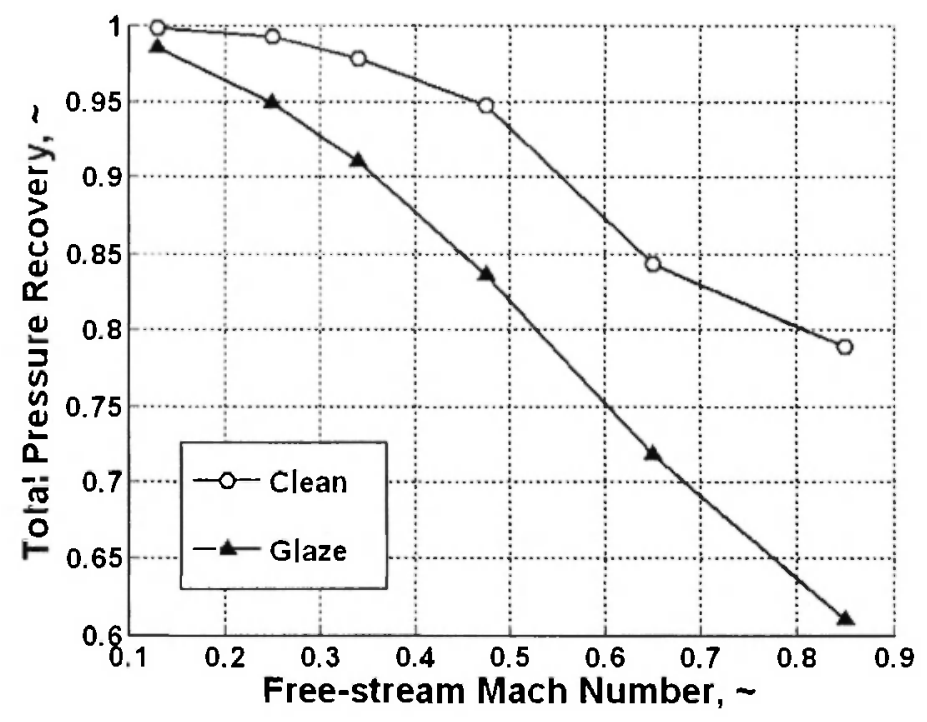

Fig. 12: Variation of total pressure recovery $\left(\overline{\mathbf{P t}}_{\mathrm{ef}} / \mathrm{Pt}_{\infty}\right)$ with free-stream Mach numbers $\left(\mathrm{Pt}_{\infty}=101.1 \mathrm{kPa}\right)$ 
Figure 12 shows mean (i.e., area-averaged) total pressure recoveries $\left(\bar{p}_{t \text { ef }} / p_{t \infty}\right)$ at the engine face in the Mach numbers range of $M_{\infty}=0.13$ to 0.85 . Reduction in the total pressure recovery of both the clean and glaze iced inlet accelerates as the freestream Mach number increases. However, the total pressure recovery of the glaze ice cases drops even faster, compared to the clean cases. Total pressure recoveries of the glaze ice case at $\mathrm{M}_{\infty}=0.13$ and 0.85 are 0.985 and 0.61 , while, those of the clean case are 0.998 and 0.789 , respectively. Therefore, the total pressure recovery is decreased by 1.3 and 22.8 percent at $M_{\infty}=0.13$ and 0.85 , respectively. The greater loss in total pressure recovery at higher Mach numbers can be explained by the stronger flow separation plus more intense and extensive shock structure in the duct flow with the glaze ice formation, as described earlier. At the relatively low free-stream Mach numbers, flow separation from the ice accretion is the main source of the total pressure loss. However, the occurrence of a nearly-periodic and strong shock structure under the icing effect at the higher Mach numbers is the major contributor to the lower total pressure reduction at the engine face.

The effect of the inlet icing on the performance of a turbofan engine system can be approximately estimated. A military specification, MIL-E-5007D $132 /$, defines the requirement for the engine performance in the icing condition. According to the specification, a turbofan engine should operate satisfactorily under the meteorological conditions with not more than 5 percent total loss in thrust available and 5 percent total increase in specific fuel consumption at all operating conditions above 50 percent maximum continuous power setting /32/ (Figure 13).

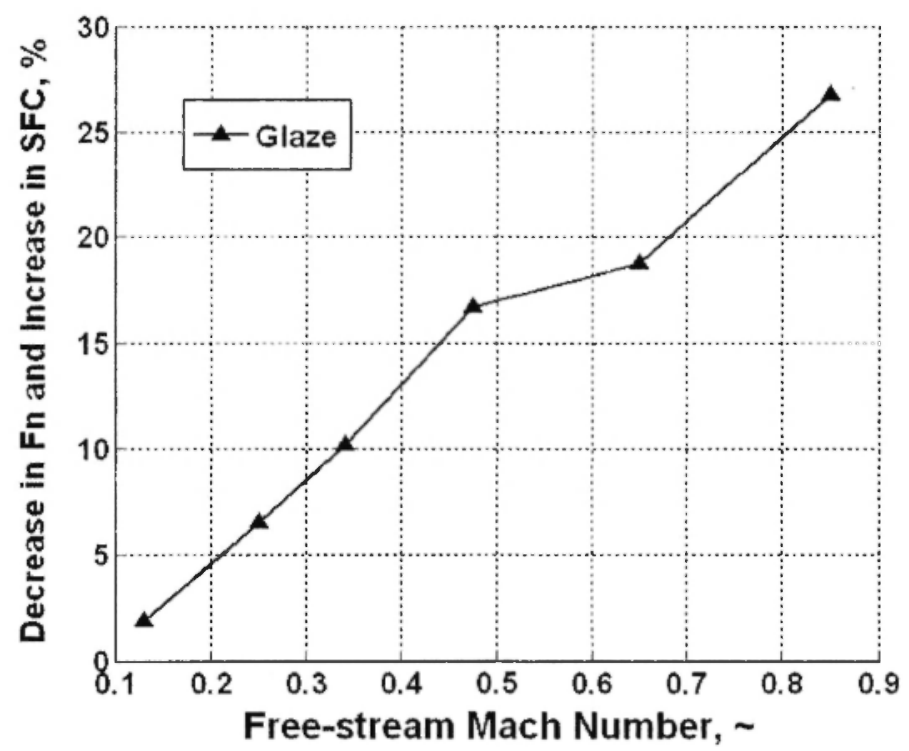

Fig. 13: Decrease in engine net thrust $\left(F_{n}\right)$ or increase in specific fuel consumption (SFC) under the glaze-icing effects

In addition, it is well-known that 1 percent reduction in inlet total pressure recovery leads to an approximately 1.5 percent drop in the net installed thrust in an aircraft gas turbine engine or equivalently about a 1.5 percent increase in its specific fuel consumption $/ 33$. Therefore, the total pressure degradation with the glaze ice at $M_{\infty}=0.85$ that is 18 percent, it corresponds to roughly a 27 percent total loss in the engine thrust $\left(F_{n}\right)$ and 27 percent increase in the specific fuel consumption (SFC). However as we shall present, a more severe loss source for the engine thrust with icing stems from a reduction in engine mass flow rate that is caused by the blockage due to ice formation. The 
overall degradation in thrust is substantial and far exceeds the limits of minimum requirement for the engine performance under the icing condition. Note that the simulations in the current study were based on simplifying assumptions of steady-state, singlephase flow, axisymmetric icing effect at sea-level condition and icing temperatures. Consequently, the degradation level of an engine performance as represented by the thrust and specific fuel consumption in an actual flight is expected to be more severe than those offered by our simulation.

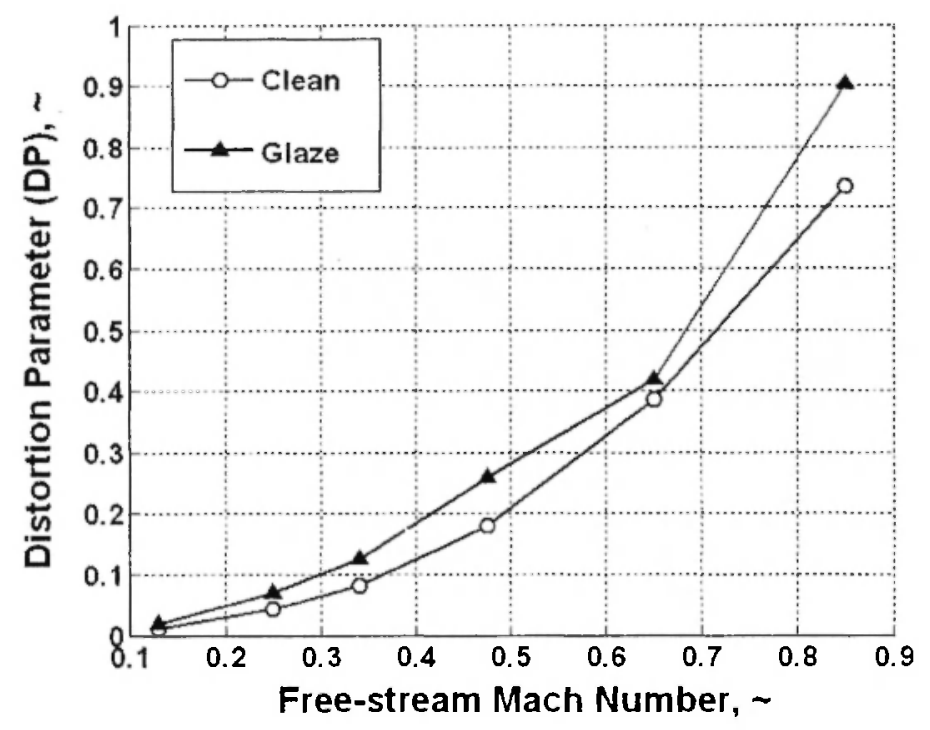

Fig. 14: Variation of total pressure distortion parameter (DP) with free-stream Mach numbers

Figure 14 shows a comparison of the total pressure distortion parameters (DP) of the clean and glaze ice cases with the free-stream Mach numbers. The total pressure distortion parameter (DP) is one possible descriptor that highlights the maximum distortion at the engine face, as defined by Eq. (3):

$\mathrm{DP}=\frac{\mathrm{p}_{\mathrm{t}, \text { max }}-\mathrm{p}_{\mathrm{t}, \text { min }}}{\bar{p}_{\mathrm{t}, \text { ef }}}$

Overall, the glaze-iced inlet induces higher DP levels compared to the clean inlet at all free-stream Mach numbers, and this fact was noted earlier in the engine face distortion patterns shown in Figure 11. In addition, the difference between the DP levels becomes more apparent as the Mach number increases, except $M_{\infty}=0.65$ case. The reason for the relatively lower DP for the glaze ice case at $M_{\infty}=0.65$ is found in the description of the distortion parameter itself, i.e., DP. In this case we note that most of the engine face is contaminated with high total pressure loss as the core flow totally disappears at $\mathrm{M}_{\infty}=0.65$ under the effect of glaze ice; therefore, the maximum total pressure, $p_{t, \text { max }}$, is comparably low as shown in Figure 11(c). However, the difference in the DP levels become the maximum at the highest Mach number, $M_{\infty}=0.18$. For the clean and glaze cases, $\mathrm{DP}=0.0 \mathrm{I}$ and 0.02 , respectively, at $\mathrm{M}_{\infty}=0.13$, while $\mathrm{DP}=0.74$ and 0.9 , respectively, at $M_{\infty}=0.85$. Hence, the engine face distortion problem is exacerbated by higher flight Mach number, as expected.

The variations of the inlet mass flow with increasing freestream Mach number are plotted in Figure 15. The inlet mass flow rate $\left(\rho_{\mathrm{ef}} \mathrm{A}_{\mathrm{ef}} \mathrm{V}_{\mathrm{ef}}\right)$ is calculated at the engine face station and it is the index of the air-swallowing capacity of an inlet. In both cases as presented in Figure 15, the increase of mass flow rate stops around $M_{\infty}=0.5$ due to the inlet 


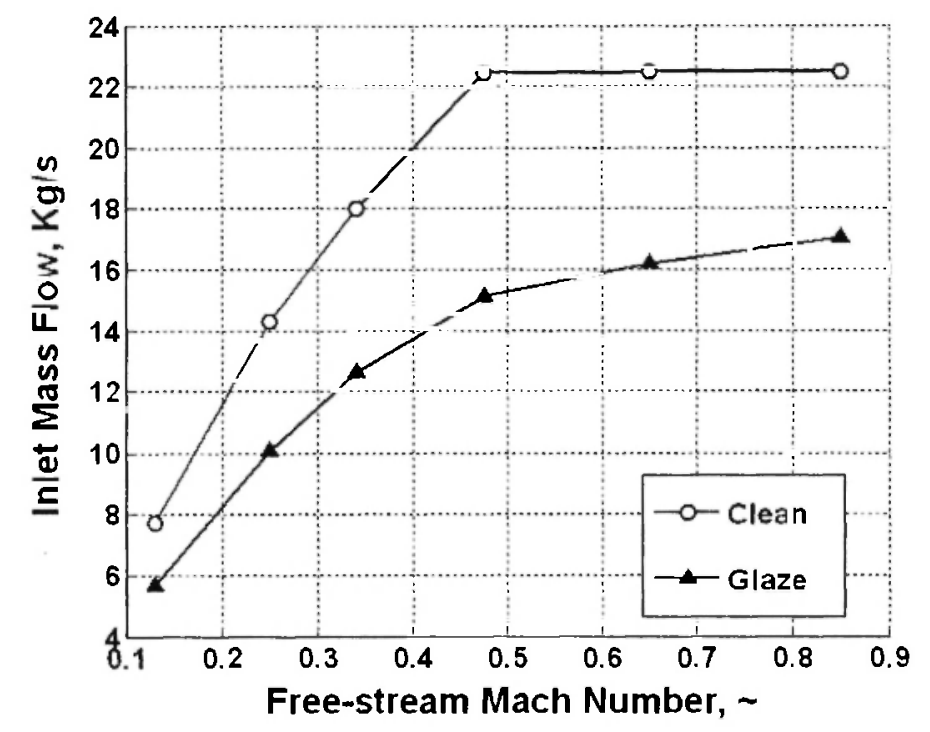

Fig. 15: Variation of inlet mass flow with free-stream Mach l.umbers

choking effect. However, the levels of inlet mass flow for the glaze ice cases are much lower than those for the clean cases, and this is mainly due to the decreased inlet frontal area by 21 percent, i.e., blockage, with the simulated glaze ice. Also, at $M_{\infty}=0.13$, the level of the mass flow rate in the glaze iced inlet is about 73 percent of that in the clean inlet, while at $\mathrm{M}_{\infty}=0.475$, which is the Mach number before choking, 'the level is approximately 67 percent. This fact suggests that when the glaze ice accretes on the inlet lip, the amount of air flow through the S-duct inlet is significantly reduced as the free-stream Mach number increases. A higher reduction in inlet mass flow rate with the higher flight Mach number, $M_{\infty}=0.475$, is caused by the more massive flow separation and blockage from the glaze ice.

In summary, our computational results indicate that a fully-developed glaze ice accretion on the inlet lip increases the total pressure loss and distortion level at the engine face of the M2129 S-duct inlet. The higher distortion levels at the engine face that are very severe may lead to compressor stall or engine surge. The loss in engine net installed thrust and increase in specific fuel consumption are caused by inlet lower total pressure recovery as well as reduced mass flow rate. Inlet icing and the attendant flow separation induced by ice horns cause an increase in inlet blockage and choking.

\section{Future Work}

We intend to relax our simplifying assumptions such as axisymmetric ice shape around the inlet by introducing asymmetrical ice shape that wraps around the inlet lip. We also intend to investigate the effect of flow angularity with angle of attack and sideslip on the flow qualities of an iced inlet. The steady-state assumption about the ice shape needs to be relaxed with time scales related to ice accretion. Therefore, a time dependent approach to temporal ice shapes and formation needs to be investigated. The dynamic distortion problem requires the time dependent calculations on a different time scale as ice accretion. In recognition of the importance of the time-resolved distortion and its impact on gas turbine engine stability, we intend to study the rootmean-square of the turbulent fluctuation at the engine face. In particular distortion levels that exceed a prescribed critical value and last on a time scale that is of the order of shaft rotation are of 
interest. Finally, time-dependent freestream flow that models atmospheric gust is of special interest. This category of externally-generated disturbance can be another source of the dynamic inlet distortion 134-35/.

\section{Acknowledgement}

The authors express their sincere appreciation to Dr. Chuan-Tau (Eddie) Lan, Emeritus Distinguished Professor of Aerospace Engineering at the University of Kansas, who has continually supported this work.

\section{References}

1. Cole, J. and Sand, W., 1991, "Statistical Study of Aircraft Icing Accidents," AIAA Paper 91-0558.

2. Potapczuk, M. G., "Numerical Analysis of an NACA 0012 Airfoil with Leading-Edge Ice Accretion," Journal of Aircraft, Vol. 25, No. 3, pp 193-194, Mar. 1988.

3. Bragg, M. B., Khodadoust, A., and Spring, S. A., "Measurement in a Leading-Edge Separation Bubble due to a simulated Airfoil Ice Accretion," AIAA Journal, Vol. 30, No. 6, pp 1462-1467, 1992.

4. Kerho, M. F and Bragg, M. B., "Airfoil Boundary-Layer Development and Transition with Large Leading-Edge Roughness," AIAA Journal, Vol. 35, No. 1, Jan. 1997.

5. Kim H. S. and Bragg, M. B., "Effects of Leading -Edge Ice Accretion Geometry on Airfoil Performance," AIAA Paper 99-3150. Jun. 1999.

6. Chung, J., Choo, Y., Reehorst, A. L., Potapczuk, M. G., and Slater, J., "Navier-Stokes Analysis of the Flowfield Characteristics of and Ice Contaminated Aircraft Wing," AIAA Paper 990375, Jan. 1999.

7. Shin, J., Berkowitz, B., Chen, H.H. and Cebeci, T., "Prediction of Ice Shapes and Their Effect on Airfoil Performance," Journal of Aircraft, Vol. 31, No. 2, pp. 263-270, 1994.
8. Acker, L. W. and Kleinknecht, K. S., "Effects of Inlet Icing on Performance of Axial-Flow Turbojet Engine in Natural Icing Conditions," NACA Research Memorandum E50C15, 1950.

9.Gelder, T. F., "Total-Pressure Distortion and Recovery of Supersonic Nose Inlet with Conical Centerbody in Subsonic Icing Conditions," NACA Research Memorandum E57G09, 1957.

10. Papadakis, M., Zumwalt, G. W., Elangonan, R., Freund, G. A., Jr., Breer, M., and Whitmer, L., "An Experimental Method for Measuring Water Droplet Impingement Efficiency on Two- and Three-Dimensional bodies," NASA-CR-4257, 1989.

11. Bidwell, C. S. and Mohler, S. R., Jr., "Collection Efficiency and Ice accretion Calculations for a Sphere, a Swept MS(1)-317 wing, a Swept NACA-0012 Wing Tip, an Axisymmetric Inlet, and a Boeing 737-300," AIAA Paper 95-0755, Jan. 1995.

12. Bidwell, C. S. and Potapczuk, M. G., "Users Manual for the NASA Lewis Three-Dimensional Ice Accretion Code (LEWICE3D), NASA TM105974, 1993.

13. Farokhi, S., "Aircraft Propulsion," Wiley, New York, USA, 2008.

14. Seddon, J. and Goldsmith, E. L., "Intake Aerodynamics," the 2 nd edition, AIAA Inc. and Blackwell Science Ltd., Osney, UK, 1999.

15. Henry, R., Guffond, D., Aschettino, S., and Duprat, G., "Characterization of Ice Roughness and Influence on Aerodynamic Performance of Simulated Ice Shapes," AIAA Paper 2001-0092, Jan. 2001.

16. Jin, W. and Taghavi, R. R., "Computational Study of Icing Effects on the M2129 S-Duct Inlet," AIAA Paper 08-0075, Jan. 2008.

17. Anderson, B. H., Reddy D. R., and Kapoor, K., "Study on Computing Separating Flows within a Diffusing Inlet S-Duct," Journal of Propulsion and Power, Vol. 10, No. 5, Sept.-Oct. 1994.

18. Addy. Jr., H. E., "Ice Accretions and Icing Effects for Modern Airfoils," NASA TP-2000210031,2000 
19. Willmer, A. C., Brown, T. W., and Goldsmith, E. L., "Effects of Intake Geometry on Circular Pitot Intake Performance at Zero and Low Forward Speeds," Aerodynamics of Power Plant Installation, pp. 5.1-5.16 (AGARD CP301, Paper 5), Toulouse, France, May 1981.

20. Gibb, J. and Jackson, M., "Some Preliminary Results from Tests Using Vortex Generators in the Circular/Circular Diffusing S-Duct Model M2129 Test Phase 3," Defense Research Agency Rept. AP4(92)WP15, Aug. 1992.

21. GAMBIT Software Package, Ver. 2.2.30, Fluent Inc., Lebanon, NH, USA, 2004.

22. STAR-CCM+ Software Package, Ver. 2.10.013, CD-adapco Inc., Melville, NY, USA, 2007.

23. Anderson, B. H. and Farokhi, S., "A study of Three Dimensional Turbulent Boundary Layer Separation and Vortex Flow Control Using the Reduced Navier Stokes Equations," Turbulent Shear Flow Symposium, Munich, Germany, Sept. 1991.

24. AGARD Fluid Dynamics Panel Working Group 13, "Air Intakes for High Speed Vehicles," AR.270, Fort Worth, TX, USA, Sept. 1991.

25. Menter, F. R., "Two-Equation Eddy-viscosity Turbulence Models for Engineering Applications," AIAA Journal, Vol. 32, No. 8, pp 1598-1605, Aug. 1994.

26. Menzies, R. D. D., Babcock, K. J., Barakos, G. N., and Richards, B. E., "Validation of the
Simulation of Flow in an S-duct," AIAA Paper 2002-2808, Jun. 2002.

27. May, N. E., "A New Vortex Generator Model for Use in Complex Configuration CFD Solvers," AIAA Paper 2001-2434, Jun. 2002.

28. Berrier, B. L. and Allan B. G., "Experimental and Computational Evaluation of FlushMounted, S-Duct Inlets," AIAA Paper 2004-764. Jan. 2004.

29. Mohler, S. R. Jr., "WIND-US Flow Calculations for the M2129 S-Duct Using Structured and Unstructured Grids," AIAA Paper 2004-525, Jan. 2004.

30. FLUENT Software Package, Ver. 6.2.16, Fluent Inc., Lebanon, NH. USA, 2005.

31. Dunham, J., "The Generation of Swirl in an SDuct with Axial Flow," NGTE unpublished memo, 1979.

32. MIL-E-5007D General Specification for Engines, Aircraft, Turbojet and Turbofan.

33. Johnson, R. W., "The Handbook of Fluid Dynamics," the lst edition, Springer publishing Co., 1998.

34. Macmiller, C. J. and Haagenson, W. R., "Unsteady Inlet Distortion Characteristics with the B-1B," the Propulsion and Energetic 68th (A) Specialists' Meeting, Munich. Germany, 1986.

35. Barry, F. W., "Effects of Atmospheric Gust Criteria on Supersonic Inlet Performance," AIAA Paper 1966-367, Mar. 1966 